\title{
Online Assignment Submission System untuk Efisiensi Pengelolaan Tugas Mahasiswa
}

\author{
Mohammad Suryawinata ${ }^{1}$, Nuril Lutvi Azizah ${ }^{2}$, Cindy Taurusta ${ }^{3}$ \\ 1,2,3 Program Studi Informatika, Fakultas Teknik, Universitas Muhammadiyah Sidoarjo \\ 1suryawinata@umsida.ac.id \\ 2nurillutvi@umsida.ac.id \\ 3cindytaurusta@umsida.ac.id
}

\begin{abstract}
Abstrak - Dalam sebuah proses pendidikan, mahasiswa akan mengikuti beberapa tahap. Mulai dari perkuliahan, mengerjakan tugas-tugas, dan mengikuti ujian, baik itu tengah semester maupun akhir semester. Proses ujian akhir semester secara tertulis masih banyak dilakukan pada matakuliah yang tidak menerapkan proyek akhir berupa perancangan sebuah system, produk atau karya tulis. Banyak dosen di Universitas Muhammadiyah Sidoarjo selama ini masih menggunakan kertas untuk proses penugasan mahasiswa seperti membuat makalah atau portofolio. Evaluasi dalam merupakan satu hal yang tidak bisa dipisahkan dari proses pendidikan. Banyak istilah yang digunakan untuk melakukan evaluasi pendidikan antara lain tes, asesmen, ujian, dan lain sebagainya. Evaluasi digunakan untuk mengetahui sejauh mana peserta didik memahami dan mempelajari materi. Selain itu evaluasi juga digunakan untuk mengetahui sejauh mana peserta didik mencapai tujuan pembelajaran. Penugasan atau pemberian tugas merupakan salah satu cara evaluasi dalam proses belajar mengajar dengan memberikan tugas pada peserta didik. Dalam penelitian ini, peneliti akan melakukan pengembangan sistem pengumpulan tugas secara online dengan mempertimbangkan efektifitas waktu dan biaya yang bisa diminimalisir. Pengumpulan tugas secara online ini penting karena dapat membantu mahasiswa dalam pengumpulan tugas agar tidak saling menunggu dengan mahasiswa lain. Serta untuk dosen, manfaat dari sistem ini diharapkan bisa menghemat waktu dalam mengorganisir tugas dan juga mengetahui urutan mahasiswa yang mengumpulkan tugas dari awal hingga akhir deadline. Hasil penelitian menunjukkan bahwa waktu pengumpulan tugas dan pengelolaan tugas oleh dosen menjadi lebih efektif.
\end{abstract}

Kata Kunci-Tugas, Online, Evaluasi, Pengelolaan, Submission

\section{Pendahuluan}

Dalam sebuah proses pendidikan, mahasiswa akan mengikuti beberapa tahap. Mulai dari perkuliahan, mengerjakan tugas-tugas, dan mengikuti ujian, baik itu tengah semester maupun akhir semester. Proses ujian akhir semester secara tertulis masih banyak dilakukan pada matakuliah yang tidak menerapkan proyek akhir berupa perancangan sebuah system, produk atau karya tulis. Banyak dosen di Universitas Muhammadiyah Sidoarjo selama ini masih menggunakan kertas untuk proses penugasan mahasiswa seperti membuat makalah atau portofolio.

Tugas seperti makalah akan dicetak pada lembaran kertas yang sifatnya hanya sekali pakai, kemudian akan menumpuk di ruang dosen atau ruang administrasi. Bahkan beberapa ada yang berceceran di ruang kelas setelah koreksi selesai dilaksanakan. Hal ini selain tidak efisien, juga menghabiskan banyak biaya dari segi pembuatan makalah saja, padahal dosen atau pendidik pada era digital ini dituntut harus lebih efisien[9]. Pada proses pengkoreksian dengan asumsi 40 mahasiswa pada tiap kelas yang diampu, dosen akan mengkoreksi jawaban pada kertas tersebut lembar per lembar. Pada soal esay non matematis, dengan contoh soal "analisislah mengapa hal ini bisa terjadi?" Dosen hanya akan terpaku untuk melihat jawaban yang benar tanpa mengetahui jawaban ini hasil mencontek atau bukan.

Ujian online merupakan salah satu ujian yang mulai dikembangkan pada tahun 2015 pada ujian nasional siswa SMA/SMK sederajat oleh Kementerian Pendidikan dan Kebudayaan. Meskipun sistem masih berupa soal pilihan ganda, namun ujian online ini diklaim telah menghemat anggaran Negara hingga 30 persen[1]. Pro kontra terkait dengan penghematan anggaran yang dapat dilakukan dengan ujian online ini masih menjadi pro konta di masyarakat. Salah satunya adalah sekolah masih harus mengeluarkan biaya untuk fasilitas komputer serta koneksi internet untuk mengakses soal ujian online ini.

Namun dengan semakin berkembangnya teknologi, perangkat seperti komputer bahkan telepon genggam sekalipun sebenarnya dapat digunakan untuk mengerjakan soal ujian online. Dari survey yang telah dilakukan oleh peneliti, lebih dari 95 persen mahasiswa telah memiliki telepon genggam yang dapat digunakan untuk mengakses Internet.

Ujian online ini bisa diadaptasi dalam lingkungan perguruan tinggi dengan model pengumpulan tugas. Hal ini dapat meningkatkan kualitas pendidikan dari segi aktivitas dan persepsi mahasiswa[3][4].

Tujuan yang ingin dicapai dengan dilakukannya penelitian ini adalah membangun sistem pengumpulan tugas online yang 
mudah diakses dan digunakan oleh civitas akademik Universitas Muhammadiyah Sidoarjo serta Meningkatkan efisiensi pada pengumpulan tugas maupun proyek akhir pada matakuliah metode penelitian di Program Studi Teknik Informatika Universitas Muhammadiyah Sidoarjo.

Urgensi penelitian ini terkait pada berjalannya sistem pengumpulan tugas secara online serta hasil perbaikan atau peningkatan efisiensi pada pengumpulan tugas yang akan dilakukan. Hal ini ke depannya akan membantu meningkatkan efisiensi pengumpulan tugas oleh mahasiswa di lingkungan UMSIDA. Hasil dari penelitian ini juga akan membantu dalam pengembangan kualitas layanan pendidikan yang diberikan oleh UMSIDA. Dengan meningkatkan kualitas layanan pendidikan, maka diharapkan penggunaan teknologi dalam prosen penyelenggaraan pendidikan ini dapat meningkatkan mutu UMSIDA baik secara internal maupun dalam proses akreditasi, baik itu program studi maupun institusi.

\section{KAJIAN PUSTAKA}

\section{A. Evaluasi Pendidikan}

Evaluasi dalam merupakan satu hal yang tidak bisa dipisahkan dari proses pendidikan. Banyak istilah yang digunakan untuk melakukan evaluasi pendidikan antara lain tes, asesmen, ujian, dan lain sebagainya. Evaluasi digunakan untuk mengetahui sejauh mana peserta didik memahami dan mempelajari materi. Selain itu evaluasi juga digunakan untuk mengetahui sejauh mana peserta didik mencapai tujuan pembelajaran[2].

Evaluasi pendidikan dirasa penting untuk dilakukan karena beberapa hal. Selain faktor utama yang telah disebutkan diatas, evaluasi juga berguna untuk membangun kepercayaan diri para peserta didik dalam menghadapi permasalahan yang akan terjadi. Evaluasi pendidikan konvensional hanya menekankan pada ujian tertulis atau dengan model menghafal materi yang telah diberikan. Di era pendidikan modern ini evaluasi tidak hanya berbentuk ujian tulis dan hafalan saja. Pendidik harus dapat melakukan evaluasi dengan kreatif dan menggunakan berbagai cara sesuai tujuan yang ingin dicapai[8]. Sebagai contoh pada program studi Teknik Informatika matakuliah pemrograman, bentuk evaluasi yang tepat dilakukan adalah dengan membuat sebuah aplikasi.

\section{B. Penugasan}

Penugasan atau pemberian tugas merupakan salah satu cara dalam proses belajar mengajar dengan memberikan tugas pada peserta didik. Tugas-tugas yang diberikan bisa berbagai macam bentuknya. Rangkuman, kliping, makalah, presentasi, dan banyak lagi yang lainnya. Metode penugasan mandiri dianjurkan karena dapat meningkatkan kualitas pembelajaran peserta didik[5]. Pemberian tugas bisa dilakukan secara individual maupun kelompok [6].

Penggunaan metode penugasan yang digunakan dalam proses belajar mengajar memiliki beberapa tujuan tertentu yakni:

- Dapat menumbuhkan proses belajar mengajar yang eksploratif

- Dapat mendorong perilaku kreatif pada peserta didik

- Dapat membiasakan peserta didik berpikir komprehensif

- Dapat memupuk kemandirian peserta didik dalam proses belajar mengajar

\section{Electronic Submission System}

Electronic submission system merupakan teknologi yang memungkinkan bagi peserta didik untuk mengumpulkan tugasnya secara daring. Sistem ini memiliki kelebihan dalam hal kecepatan pengiriman tugas[7]. Sistem ini juga memungkinkan hilangnya masalah-masalah umum yang terjadi selama proses pengumpulan tugas, seperti misalnya tugas tertindih dengan tugas peserta didik lain. Electronic submission system memiliki banyak bentuk seperti e-mail, web, maupun form daring. Gambar 1 menunjukkan contoh electronic submission system

\section{Assignment 1 - File submission}

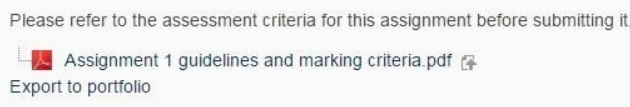

\section{Submission status}

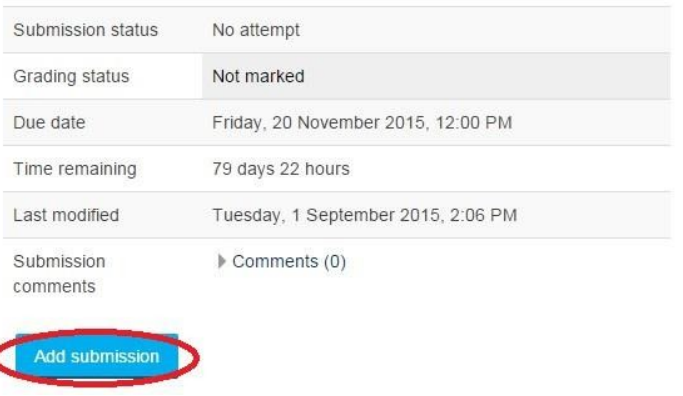

Gambar 1. Contoh Electronic Submission System

\section{METODOLOGI}

Langkah-langkah penelitian yang akan dilakukan pada penelitian ini adalah sebagai berikut:

\section{A. Perumusan Masalah}


Masalah utama yang dihadapi dalam penelitian ini adalah masih belum adanya sistem pengumpulan tugas secara online di Universitas Muhammadiyah Sidoarjo. Saat ini beberapa dosen sudah menerapkan pengumpulan tugas melalui email. Namun hal ini masih kurang efisien, karena dosen harus memeriksa email dan melakukan pengunduhan tugas per mahasiswa. Belum lagi kasus mahasiswa yang mengumpulkan tugas melewati waktu yang telah disepakati.

Berangkat dari permasalahan ini penulis mengemukakan sebuah ide untuk mengatasi permasalahan tersebut dengan cara membuat sebuah sistem yang dapat memfasilitasi pengumpulan tugas mahasiswa secara online. Hal ini dapat memudahkan dosen dalam melakukan pemeriksaan terhadap tugas-tugas mahasiswa yang dikumpulkan. Dengan sekali klik, semua tugas mahasiswa akan terunduh ke perangkat dosen.

\section{B. Studi Literatur}

Dalam tahap studi literatur, dikaji berbagai referensi yang berkaitan dengan metode pengumpulan tugas yang sudah dikembangkan pada saat ini seperti pengumpulan tugas melalui surat elektronik, bahkan masih ada yang menggunakan media penyimpanan fisik seperti CD atau flash drive. Selain itu kan dikaji pula hal-hal yang mendukung penelitian ini.

\section{Desain Sistem}

Dalam penelitian yang akan dilakukan ini digunakan beberapa langkah yakni:

1. Penentuan populasi dan sampel

Dalam proses ini, akan ditentukan populasi dan sampel dalam penelitian ini. Populasi dalam kasus ini adalah seluruh civitas akademik di UMSIDA. Sedangkan sampel yang akan diambil adalah mahasiswa yang mengambil matakuliah metode penelitian di kelas 5A1 Teknik Informatika Fakultas Teknik Universitas Muhammadiyah Sidoarjo.

2. Penentuan parameter uji coba

Proses penentuan parameter uji coba merupakan proses untuk menentukan batasan-batasan apa saja yang digunakan dalam penelitian ini serta apa saja yang diukur/dihitung. Parameter yang digunakan dalam penelitian ini adalah:

a. Efektifitas waktu pengumpulan tugas oleh mahasiswa

b. Efektifitas waktu pengunduhan tugas oleh dosen

3. Pemilihan skenario uji coba

Proses pemilihan skenario uji coba merupakan proses dimana kita harus melakukan pengujian dengan salah satu skenario yang kemudian dilalukan secara berulang-ulang hingga semua data didapatkan.
4. Pengukuran hasil uji coba

Pengukuran hasil uji coba dilakukan untuk mengukur data yang dihasilkan dari skenario uji coba yang telah dilakukan.

5. Analisis hasil uji coba

Analisis hasil uji coba bertujuan untuk mentelaah hasil yang telah diperoleh dari proses pengujian apakah data telah sesuai dengan hipotesis awal atau tidak.

6. Evaluasi

Evaluasi dilakukan untuk me-review hasil pengujian, kelemahan- kelemahan yang ada serta saran dan masukan untuk penelitian selanjutnya.

\section{Desain Algoritma dan Implementasi}

Desain sistem pada penelitian ini ditunjukkan pada Gambar 2. mahasiswa akan melakukan pengumpulan tugas pada alamat yang sudah disediakan oleh dosen pengampu matakuliah. Langkah pertama yang harus dilakukan adalah mahasiswa mengakses alamat sistem yang telah diberikan oleh dosen. Selanjutnya mahasiswa akan mengisi identitas yang terdiri dari nama, NIM, dan kelas dimana dia mengambil matakuliah ini. Setelah biodata diisi, maka mahasiswa akan dapat mengumpulkan tugas melalui isian yang tersedia. Mahasiswa akan memilih file tugas pada komputernya masing-masing, kemudian akan diunggah di sistem. Proses pengunggahan tugas sudah selesai dilakukan.

Dosen yang juga berperan selaku administrator sistem, akan dapat melihat data-data mahasiswa yang sudah melakukan pengumpulan tugas. Data yang bisa dilihat sesuai dengan yang diinputkan oleh mahasiswa ketika mengumpulkan tugas. Dosen dapat memilih antara mengkoreksi langsung tugas melalui sistem yang telah dibuat atau mengunduh seluruh tugas-tugas yang telah dikumpulkan lalu mengkoreksinya ketika sempat. Proses ini diharapkan akan meningkatkan efisiensi dari proses pengumpulan tugas baik bagi mahasiswa maupun dosen.

Proses pengumpulan tugas telah dirancang seluruhnya melalui sistem online. Pengumpulan tugas ini dapat memberikan format pengumpulan yang sesuai dengan apa yang diharapkan dosen. Selama ini pengumpulan dokumen tugas tidak beratur nama filenya. Dengan sistem ini maka proses pengumpulan tugas diharapkan menjadi lebih terstruktur dan lebih efisien. 


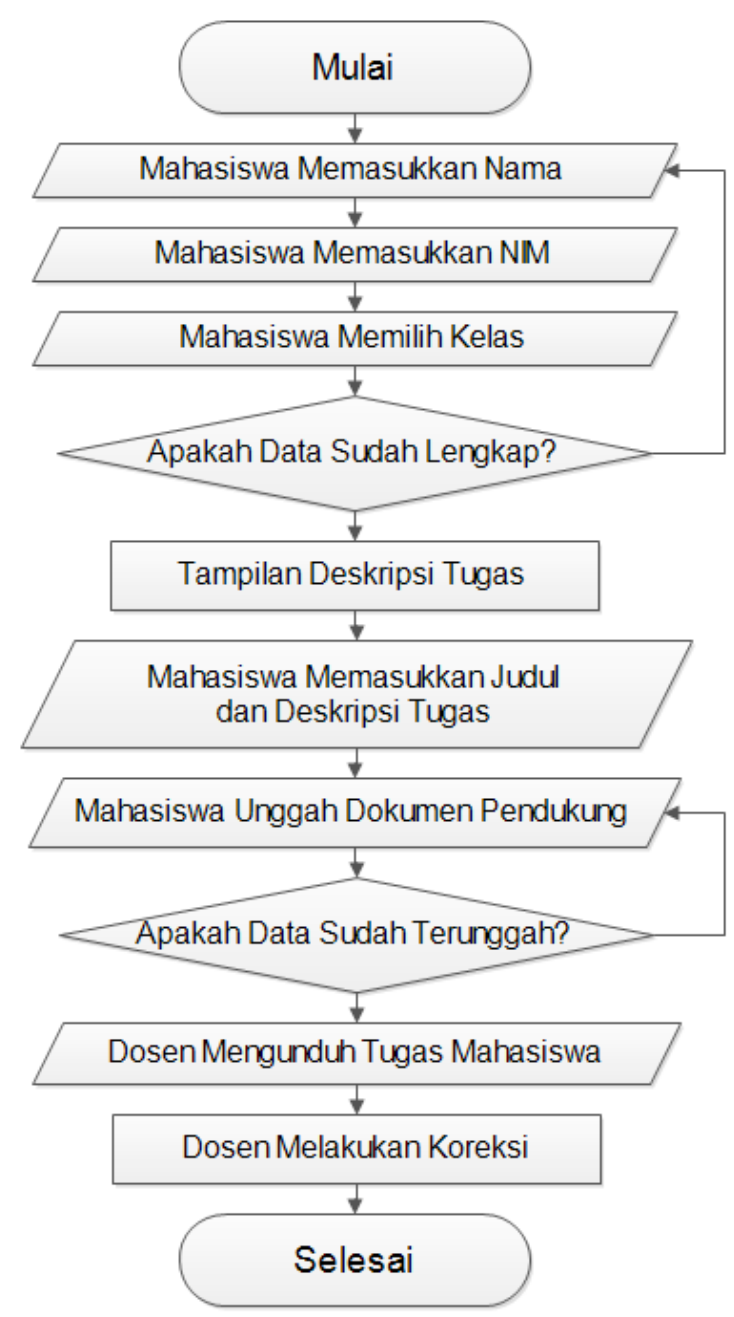

Gambar 2. Flowchart Sistem

\section{E. Perancangan User Interface}

Gambar 3. Menunjukkan mockup tampilan awal sistem yang akan dibuat. Tampilan ini berisi identitas mahasiswa selaku pengumpul tugas yang harus diisi sesuai dengan identitas aslinya.

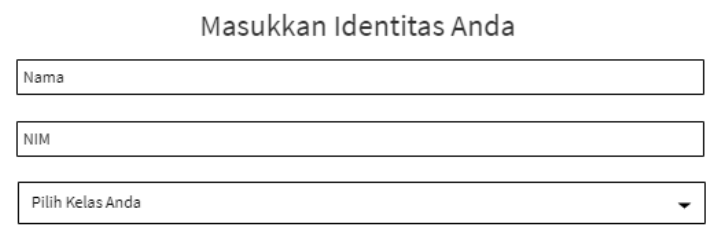

Gambar 3. Halaman Profil Pengunggah
Gambar 4. menunjukkan mockup tampilan utama yakni pengunggahan dokumen yang telah dikerjakan oleh mahasiswa. Mahasiswa akan memilih file yang akan diunggah ke dalam sistem, kemudian klik upload untuk memasukkan dokumennya.

Unggah Dokumen yang Diperlukan

\begin{tabular}{|l|l|}
\hline Nooose File & Nole Choosen \\
\hline & Upload \\
\hline
\end{tabular}

Gambar 4. Halaman Unggah Dokumen

Proses pembuatan sistem dimulai dengan melakukan analisis kebutuhan terkait dengan online assignment submissission system initerkait dengan pengumpulan tugas, maka sistem harus bisa mengidentifikasi beberapa data yang terkait dengan mahasiswa. Data-data tersebut antara lain nomor induk mahasiswa (NIM), nama lengkap mahasiswa, serta kelas. Sistem juga dirancang untuk mencatat waktu pengumpulan tugas oleh masing-masing mahasiswa. Dalam proses pembuatan sistem, dilalui beberapa tahap, yakni tahap awal pembuatan sistem dengan membuat user interface yang sesuai dengan proposal yang diajukan. Sistem terdiri dari beberapa bagian dengan fungsi atau tujuan yang berbeda, mulai dari pengisian identitas, judul tugas, deskripsi tugas, hingga ke proses unggah tugas. Namun setelah melalui beberapa ujicoba dan evaluasi, sistem terus menerus mengalami perbaikan hingga akhirnya didapatkan versi final. Versi final ini jauh lebih sederhana dan lebih user friendly.

Tampilan online assignment submissission system yang telah selesai dibuat ditunjukkan pada gambar 5. Dari tampilan yang telah dibuat, terlihat bahwa sistem dirancang sedemikian rupa karena user-friendlyness merupakan salah satu faktor yang penting utnuk perancangan aplikasi[10]. Mahasiswa dapat mengakses 1 halaman untuk semua proses pengumpulan tugas. Hal ini akan memudahkan mahasiswa untuk melakukan pengumpulan tugas, terlebih jika ada masalah koneksi yang tidak stabil. Koneksi yang tidak stabil dapat menyebabkan mahasiswa mengisi form pengumpulan tugas berkali-kali. Namun dengan desain yang dikemas menjadi 1 halaman, jika ada masalah koneksi, mahasiswa tidak perlu mengisi ulang form namun cukup dengan menekan tombol back atau refresh. 


\section{Monitoring PKM GT - Revisi Akhir}

\author{
Bagian Pendahuluan \\ Nama dan foto yang terkait dengan akun Google Anda akan direkam saat Anda mengupload file \\ dan mengirimkan formulir ini. Bukan suryawinata@umsida.ac.id? Ganti akun \\ *Wajib \\ Alamat email * \\ Email Anda \\ NIM Anda (Ketua) * \\ Jawaban Anda \\ NIM Anda (Anggota) * \\ Jawaban Anda \\ Unggah Progress PKM Anda * \\ Format Nama File "NIM - NIM.pdf" contoh "145632544012 - 21567171209.pdf" \\ TAMBAHKAN FILE \\ Salinan tanggapan Anda akan dikirimkan melalui email ke alamat yang Anda \\ berikan.

\section{KIRIM} \\ Jangan pernah mengirimkan sandi melalui Google Formulir.
}

\section{Gambar 5. Tampilan Sistem}

Pada tampilan sistem yang ditunjukkan pada Gambar 4.1. terlihat bahwa mahasiswa wajib melampirkan alamat email yang digunakan. Fitur ini berfungsi untuk memberikan konfirmasi bahwa mahasiswa yang bersangkutan telah berhasil mengunggah jawabannya. Pesan akan secara otomatis dikirimkan oleh sistem ke email mahasiswa yang dimasukkan pada saat pengisian form. Tampilan fitur email konfirmasi ditunjukkan pada gambar 6 .

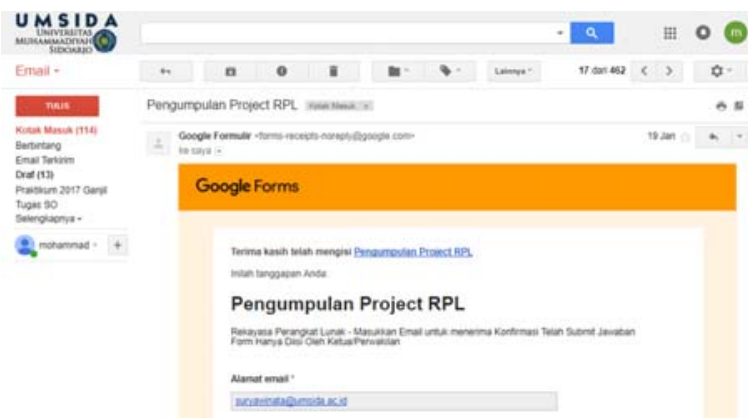

Gambar 6. Fitur Balasan via Email untuk Konfirmasi Penerimaan Jawaban
Setelah seluruh mahasiswa mengumpulkan tugasnya melalui sistem yang telah dibuat, maka dosen akan mengakses direktori sistem yang telah diatur sebagai tempat penyimpanan file yang diunggah oleh mahasiswa. Dalam folder ini telah berisi file-file yang telah diunggah oleh mahasiswa. Tampilan direktori untuk tempat mahasiswa mengunggah file ditunjukkan pada Gambar 7. Dari sini terlihat bahwa dalam sistem yang sudah diimplementasikan, dosen hanya cukup mengakses satu direktori saja untuk mengakses semua tugas mahasiswa, kapan saja dan dimana saja tanpa harus menunggu proses pengumpulan tugas yang membutuhkan waktu relatif lama.

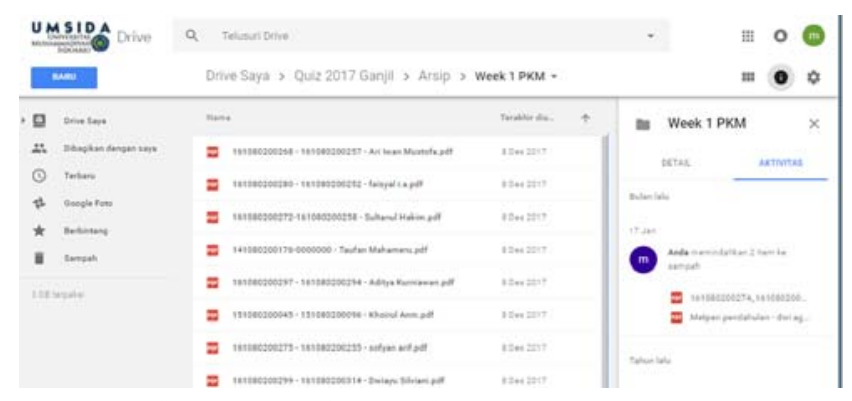

Gambar 7. Tampilan Direktori Penyimpanan Tugas Mahasiswa

Selain fitur pengumpulan tugas yang lebih efisien, dalam sistem ini juga telah terdapat perekaman waktu mahasiswa mengunggah tugasnya. Dari fitur ini dosen dapat mengetahui mahasiswa mana yang mengupload tugasnya di awal waktu. Dari data yang didapatkan maka dosen akan bisa memberikan poin khusus untuk mahasiswa yang rajin dalam mengumpulkan tugasnya. Gambar 8. menunjukkan hasil pengumpulan tugas mahasiswa melalui sistem. Statistik dapat dilihat dengan bentuk grafis atau dalam bentuk lembar sebar.

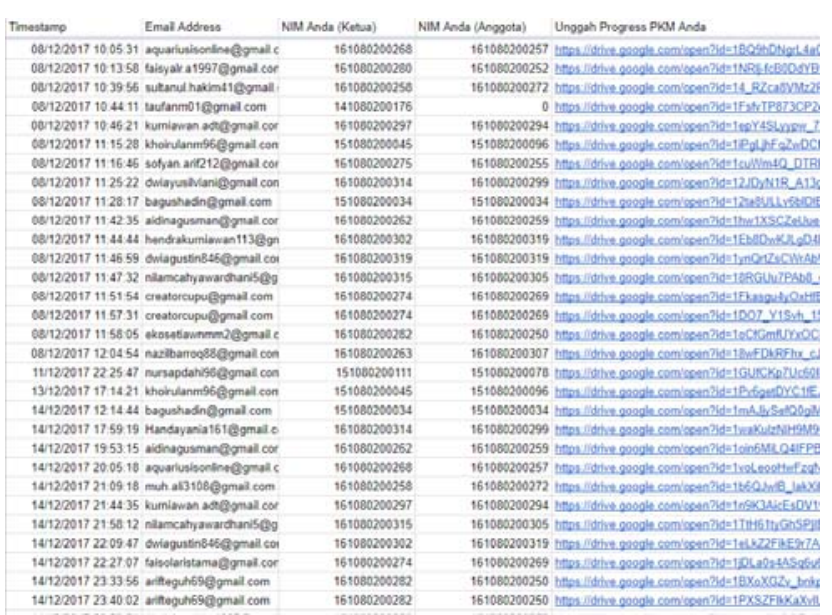

Gambar 8. Statistik Pengumpulan Tugas Mahasiswa 


\section{F. Pengujian dan Evaluasi}

Lingkungan uji coba pada proposal penelitian ini meliputi hardware dan software yang digunakan selama proses pengujian dan evaluasi berlangsung. Ada beberapa macam hardware yang digunakan dalam uji coba ini yakni:

Web Server

Spesifikasi Hardware :

- Prosesor

: Intel Core2Duo T6400 2,40 GHz

- Memori

: 2 GB DDR3

- Harddisk

: 250 GB SATA

- NIC

: TP Link Gigabit Ethernet

- Sistem Operasi : Ubuntu Server 14.04

Accessing Device

Spesifikasi Hardware :

- Prosesor

: Minimum Processor $1 \mathrm{GHz}$

- Memori

$: 1 \mathrm{~GB}$

- WiFi

: $802.11 . \mathrm{b} / \mathrm{g} / \mathrm{n}$

- Jaringan

: Minimum $128 \mathrm{Kbps}$

- Sistem Operasi : GUI Based OS

Rencana uji coba akan dilakukan dengan menggunakan uji coba langsung dengan menggunakan sampel beberapa perangkat dengan jenis yang berbeda. Uji coba akan dilakukan untuk mengukur keberhasilan sistem pengumpulan tugas yang ada pada Server dan client. Indikator keberhasilan evaluasi dilihat dari tingkat keberhasilan submission jawaban yang dikirimkan oleh mahasiswa ke dalam sistem.

Skenario pengujian yang digunakan adalah melakukan pengujian terhadap masing masing variabel secara independen, dan kombinasi antara seluruh variabel yang digunakan. Skenario pengujian pada uji coba fungsionalitas ini digunakan untuk menguji kesesuaian konten yang ditampilkan oleh sistem dengan desain interface yang telah dirancang sebelumnya.

Tabel 3.3 Rule Uji Coba Berdasarkan Fungsionalitas Program

\begin{tabular}{|c|c|c|c|}
\hline No & Fungsionalitas & Berfungsi & $\begin{array}{c}\text { Tidak } \\
\text { Berfungsi }\end{array}$ \\
\hline 1 & Fitur Mengisi NIM & V & \\
\hline 2 & Fitur Mengisi Nama & V & \\
\hline 3 & Fitur Memilih Kelas & V & \\
\hline 4 & Fitur Deskripsi Tugas & V & \\
\hline 5 & Fitur Unggah Tugas & V & \\
\hline 6 & Validasi Tipe File & V & \\
\hline 7 & $\begin{array}{c}\text { Akses Direktori } \\
\text { Pengumpulan Tugas }\end{array}$ & V & \\
\hline 8 & Download Tugas & V & \\
\hline
\end{tabular}

\section{G. Analisis Hasil}

Analisis hasil dilakukan untuk mengetahui apakan hasil yang dicapai sesuai dengan tujuan penelitian. Analisis hasil dilakukan pada hasil ujicoba berdasarkan skenario pengujian yang telah dilakukan. Dari hasil pengujian yang telah dilakukan, diketahui bahwa sistem dapat berjalan dengan tingkat keberhasilan $100 \%$. Kendala-kendala yang terjadi pada penggunaan sistem adalah masalah eksternal yakni koneksi pada sisi klien yang tidak stabil sehingga menyebabkan putusnya koneksi pada waktu pengiriman tugas. Namun hal ini dapat diantisipasi dengan adanya fitur konfirmasi dari sistem bahwa mahasiswa yang bersangkutan telah mengumpulkan tugas. Jika belum menerima email balasan, maka dapat dipastikan bahwa tugasnya belum diterima oleh sistem.

\section{KESIMPULAN DAN SARAN}

Dari hasil pengujian dan analisis hasil yang telah dilakukan pada penelitian ini, maka dapat ditarik kesimpulan sebagai berikut:

1. Online Assignment Submission System yang telah dibuat telah berfungsi dengan baik. Tingkat keberhasilan fitur yang ditawarkan mencapai 100\%.

2. Penggunaan Online Assignment Submission System yang telah dilakukan pada matakuliah metodologi penelitian di program studi informatika pada semester ganjil tahun 2017 dapat meningkatkan efisiensi pengumpulan tugas. Waktu yang awalnya tersita hanya untuk menyalin file dari masing-masing mahasiswa ke komputer dosen bisa dimanfaatkan untuk waktu tatap muka yang lebih panjang sehingga materi yang diberikan pada matakuliah dan proses diskusi bisa menjadi lebih luas.

Online Assignment Submission System yang merupakan salah satu bagian dari e-learning masih menjadi topik yang menarik utnuk dikembangkan. Mulai dari validasi data hingga pengolahan data dan file. Dari sekian banyak metode submisi yang telah diusulkan dan dikembangkan oleh penelitian terdahulu, tentunya masih banyak aspek yang bisa dikembangkan. Salah satunya adalah dengan mengintegrasikan sistem ini dalam platform e-learning apapun yang digunakan. Selain itu pengembangan juga dapat dilakukan pada sisi kemampuan server dan klien untuk tetap menangani pemrosesan data pada bandwidth yang kecil.

\section{UCAPAN TERIMA KASIH}

Terima kasih disampaikan kepada Universitas Muhammadiyah Sidoarjo yang telah menjadi penyandang dana atas penelitian ini. Terima kasih turut disampaikan 
kepada Tim JIEET yang telah meluangkan waktu untuk membuat template ini.

\section{REFERENSI}

[1] VivaNews, "UN Komputer Hemat Anggaran Negara 30\%", Online http://www.viva.co.id/berita/nasional/613492-menteri-anies-unkomputer- hemat-anggaran-negara-30-persen. Diakses 1 Oktober 2017.

[2] Romiszowski, A.J. "The Selection and Use of Instructional Media", Kogan Page, London, 1998

[3] Soffer, T. Kahan, T. Livne, E., "E-assessment of online academic courses via students' activities and perceptions" Studies in Educational Evaluation Volume 54, September 2017, Hal 83-93

[4] Daugherty, K.K., Bodenberg, M., "Teaching students to become effective educators through an academic elective course" Currents in Pharmacy Teaching and Learning Vol. 9, Issue 2, March-April 2017, Hal. 246-254

[5] Joyce, J., Gitomer, D. H., Iaconangelo, C. J., "Classroom assignments as measures of teaching quality" Learning and Instruction, Online 13 September 2017
[6] Fook, C. Y., Sidhu, K. G., "Investigating Learning Challenges Faced by Students in Higher Education" Procedia - Social and Behavioral Sciences Volume 186, 13 May 2015, Pages 604-612

[7] Welch, S. J., "Avoiding Common Problems During Online Submission of Manuscripts" Chest Volume 131, Issue 5, May 2007, Pages 15911594

[8] Kuo, H., Burnard, P., McLellan, R., Cheng, Y., Wu, J., "The development of indicators for creativity education and a questionnaire to evaluate its delivery and practice" Thinking Skills and Creativity, Volume 24, 2017, Pages 186-198,

[9] Elen J. Instefjord, E.J., Munthe E., "Educating digitally competent teachers: A study of integration of professional digital competence in teacher education", Teaching and Teacher Education, Volume 67, 2017, Pages 37-45,

[10] Lapets,A., Kfoury, A., "A User-friendly Interface for a Lightweight Verification System", Electronic Notes in Theoretical Computer Science, Volume 285, 2012, Pages 29-41. 